\title{
p53 mutations and DNA ploidy in colorectal adenocarcinomas
}

\author{
Paola Campomenosi ${ }^{\text {a }}$, Paola Assereto ${ }^{\text {a }}$, Massimo Bogliolo ${ }^{\text {a }}$, Gilberto Fronza ${ }^{\text {a }}$, \\ Angelo Abbondandolo ${ }^{\mathrm{a}, \mathrm{b}}$, Antonella Capasso ${ }^{\mathrm{c}}$, Patrizia F. Bellomo ${ }^{\mathrm{c}}$, Roberto Monaco ${ }^{\mathrm{c}}$, \\ Anna Rapallo ${ }^{\mathrm{d}}$, Andrea Sciutto ${ }^{\mathrm{d}}$, Roberto Orecchia ${ }^{\mathrm{d}}$, Elio Geido ${ }^{\mathrm{d}}$ and Walter Giaretti ${ }^{\mathrm{d}, *}$ \\ ${ }^{\text {a }}$ CSTA-Mutagenesis Laboratory, National Cancer Institute-Genova, Genoa, Italy \\ ${ }^{\mathrm{b}}$ Chair of Genetics, Department of Clinical and Experimental Oncology, University of Genoa, \\ Genoa, Italy \\ ${ }^{\mathrm{c}}$ Cardarelli Hospital, Naples, Italy \\ ${ }^{\mathrm{d}}$ Biophysics and Cytometry Laboratory, National Cancer Institute-Genova, Genoa, Italy
}

Received 16 December 1997

Revised 30 March 1998

Accepted 5 June 1998

\begin{abstract}
The p53 tumour suppressor gene has an important role in the the maintenance of genome stability and its mutational inactivation may be at the origin of aneuploidy in cancer cells. The aim of this study was to determine whether p53 mutations were associated to DNA aneuploidy, as assessed by flow cytometry, in colorectal adenocarcinomas. Analysis of p53 mutations spectrum of the sorted nuclei was done by Denaturing Gradient Gel Electrophoresis (DGGE) and DNA sequencing. Overall, we studied 20 adenocarcinomas, the corresponding control mucosa, and 7 lymph node metastases.

Five tumours (25\%) were DNA diploid, while 15 tumours (75\%) were composed of DNA aneuploid and diploid subpopulations. DNA diploid control mucosa and adenocarcinomas showed no p53 mutations, while $60 \%$ of the tumours with DNA aneuploidy had p53 mutations. Therefore, p53 mutations occurred significantly more often in DNA aneuploid than in DNA diploid tumours $(p<0.04$, Fisher's exact test). Incidences of DNA aneuploidy and p53 mutations in lymph node metastases were 60 and $86 \%$, respectively. In all tumours showing a p53 mutation, the wild-type allele was not or only bearly visible in DNA aneuploid cells suggesting that, in such cells, aneuploidy is accompanied by complete p53 functional inactivation.

The present observations suggest that p53 mutations may have a role in the origin of aneuploidy at late stages of colorectal carcinogenesis.
\end{abstract}

\section{Introduction}

Human colorectal cancer, during its well defined progressive stages [33,41], is characterized by a series of inherited and/or acquired gene defects [5,6,11,21,22,30,35,40,42,43]. Among these, p53 mutations appear to represent an important event for late tumour progression [21,42]. A role of p53 in the control of genome stability has been proposed [29] and is supported by several pieces of evidence. Fibroblasts from Li Fraumeni patients, heterozygous for p53 mutation, showed aneuploidy at early passages of subcultivation [3]. Furthermore, studies on Barrett's esophagus showed that loss or inactivation of p53 is associated

\footnotetext{
*Corresponding author: Dr. Walter Giaretti, Laboratorio di Biofisica e Citometria, Istituto Nazionale per la Ricerca sul Cancro, Largo Rosanna Benzi, n. 10, 16132 Genova, Italy. Tel.: 010 5600969; Fax: 010 5600711; E-mail: giaretti@ hp380.ist.unige.it.
} 
with tetraploidy and aneuploidy [4,34]. Finally, the results obtained by Cross et al. [17] indicate that the p53 protein is a component of the spindle checkpoint in mouse cells in culture and might be associated to aneuploidy. It is therefore conceivable that aneuploidy and other manifestations of genomic instability often found in neoplasms, might be triggered by loss of the p53 function.

Two recent studies $[12,16]$ suggested that immunocytochemical positivity for $\mathrm{p} 53$ protein in colorectal adenocarcinomas, usually associated with p53 gene alterations [13], preceded and apparently facilitated the generation of DNA tetraploid subclones. In another study, Costa et al. [15] found, instead, that p53 mutations or loss of heterozygosity ( $\mathrm{LOH})$ were not generally associated with DNA aneuploidy. Moreover, Meling et al. [31] found that LOH in the vicinity of the p53 gene was associated with DNA aneuploidy only in those colorectal carcinomas in which the LOH extended to both arms of chromosome 17. In early adenomas, aneuploidy was observed in about $30 \%$ of cases [24], whereas p53 mutations were rare $[42,43]$. There is, therefore, no consensus on the association of p53 mutations and aneuploidy in colorectal cancer. It is known, in fact, that DNA aneuploidy is already present in the adenoma precursors of adenocarcinomas, from about $30 \%$ up to $70 \%$ corresponding to small adenomas to adenomas bearing early cancer, whereas p53 mutations are rare.

A possible way to address this question is to determine the incidence of p53 mutations in DNA diploid and DNA aneuploid tumours. If p53 mutations represented the only mechanism of aneuploidization, all tumours characterized by DNA aneuploidy should be p53 mutated.

Flow cytometry based on forward and perpendicular scattering and DNA content was applied to DAPI stained suspension of nuclei to sort out DNA diploid (DId) and aneuploid (DIa) nuclei. Using a PCRbased DGGE approach, flow cytometrically sorted nuclei were screened for the presence of genomic p53 mutations in exons 5-8 encompassing 4 highly conserved domains of the p53 protein. More than $90 \%$ of known p53 mutations reported so far in human tumours occur in this region [28], corresponding to the core of the protein involved in sequence specific DNA binding [14]. DNA sequencing was then performed on the DGGE variants.

Lymph node metastases, when present, were also analyzed following the same procedures.

\section{Material and methods}

\subsection{Tumour material and histology}

Twenty partial large bowel resections were used to obtain multiple samples from 20 human adenocarcinomas. An accurate sampling was first done using liquid-nitrogen frozen tumour material. Multiple hematoxylin-eosin stained cryostatic sections were used as histotopographic references. Areas with necrotic cells were identified and removed from the confining frozen material. Similarly, areas with prevalent muscle and connective tissue were discarded. Samples were obtained from superficial and deep invasive tumour margins (Fig. 1(A)). Samples to be later used for flow cytometry and sorting combined with multiple molecular genetic analyses (including K-ras2 and p53 mutations, deletions at 1p, aneusomy of various chromosomes) were stored without fixation at $-80^{\circ} \mathrm{C}$.

A reference sample was fixed, instead, in $10 \%$ buffered formalin for $24 \mathrm{~h}$ and embedded in paraffin. The paraffin blocks were handled according to customary protocols for the histological diagnosis and grading by the criteria of Astler and Coller [1] and WHO [32]. Astler-Coller stages were B1 in 2, B2 in 8, and C2 in 10 cases. Differentiation degree was moderate in 15 and poor in 5 cases. Adenocarcinomas were located in the left bowel in 12 cases and in the right bowel in 8 . Patients were 8 females and 12 males, aged 35-93 years (median, 68 years). 


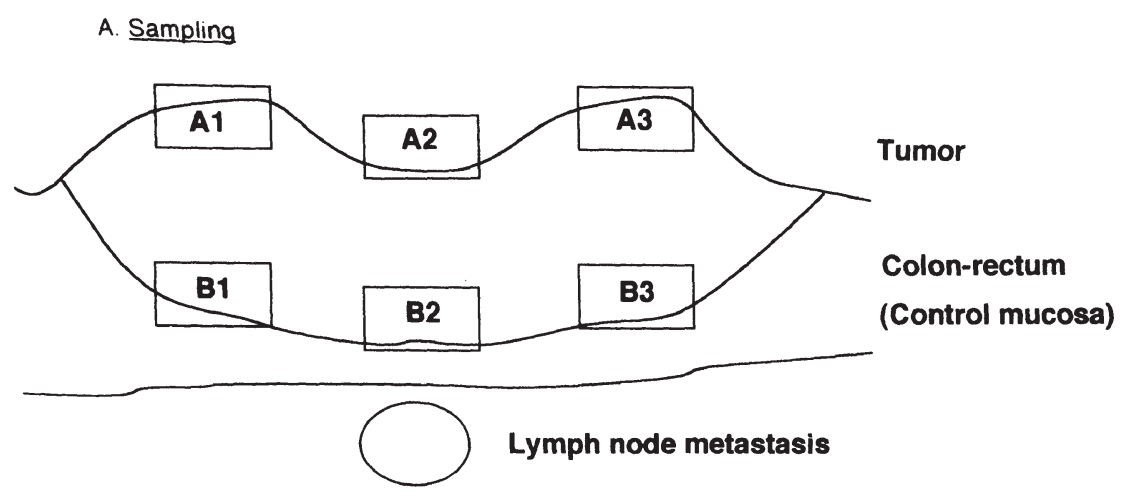

B. FACS analysis and sorting

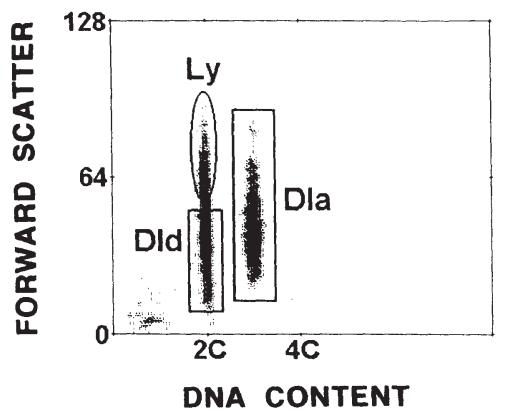

\footnotetext{
1) Dld sorting window for the DNA diploid component

2) Dla: sorting window for the DNA aneuploid component

3) Ly: Iymphocytes excluded from the sorting window DId.

C. 053 mutation spectrum analysis

1) DNA extraction from 4.000 sorted nuclei from DId and Dla sorting analysis 2) Long PCR (exons 4 to 9 ).

3) 5 Melting specific $P C R$ amplification (exon 5 to 8$)(5 A, 5 B, 6,7,8)$.

4) DGGE analysis (5A, 5B, 6, 7, 8).

5) DGGE variant are confirmed by repeating steps 2 to 4 from another DNA aliquot.

6) Sequencing of DGGE variants
}

Fig. 1. Schematic outline of the experimental procedures. Samples of tissue were obtained from multiple sites of the tumour (A). Two separate analyses were performed, respectively, for superficial and deep tumour sectors. (B) shows an example of flow cytometric analysis of forward scatter versus DNA from DAPI stained nuclei suspensions. As previously shown [25], this approach was useful to separate DNA diploid (2C) inflammatory cells (Ly) from DNA diploid (DId) and aneuploid (DIa) cell components. (C) shows the main steps of the procedure for the analysis of p53 mutation spectrum using flow cytometric sorted nuclei. Separate analyses were performed for DIa and DId cell components with exclusion of inflammatory cells.

\subsection{DNA fluorescence activated flow cytometry and sorting}

Nuclei suspensions from fresh-frozen material were prepared and stained with 4,6-diamidino-2phenilindole-2-hydrochloride (DAPI, Sigma Chemical Co., St. Louis, MO, USA) using multiparameter flow cytometric measurements and sorting as previously detailed $[25,26]$. Briefly, nuclei from the inflammatory cell component were recognized and excluded according to high values of $0^{\circ}$-forwardscattering and 2c-DNA content. Tumour samples were analyzed together with the 20 matching histologically proven control mucosa samples and 7 lymph node metastases. For tumours characterized by DNA aneuploid subpopulations, both DNA diploid and aneuploid nuclei were sorted (Fig. 1(B)). DNA 
content of tumour nuclei was evaluated relative to DNA content of tissue-specific and individual-specific histologically proven control mucosa and tissue-infiltrating lymphocytes.

\subsection{PCR conditions}

Sorted nuclei were stored at $-80^{\circ} \mathrm{C}$. Before use, nuclei were washed $30 \mathrm{~min}$ at $1500 \times \mathrm{g}$ in phosphate buffered saline, resuspended in 1X Polymerase Chain Reaction (PCR) buffer (Promega, Madison, WI, USA) and heated to $100^{\circ} \mathrm{C}$ for 10 min before PCR reaction [7]. Starting from about 4000 nuclei, the genomic region encompassing exons 4-9 was first amplified as described by Nigro et al. [36]. Nested PCRs were performed using 5 pairs of melting domain specific primers (exon 5 was amplified using two sets of primers, obtaining the $5^{\prime}$ half, $5 \mathrm{~A}$, and the $3^{\prime}$ half, $5 \mathrm{~B}$, of the exon) [8]. PCRs were performed using about 1/100th of the first PCR product (exons 4-9), 15 pmol of each primer, $250 \mu \mathrm{M}$ each dNTP, $50 \mathrm{mM} \mathrm{KCl}, 10 \mathrm{mM}$ Tris $\mathrm{HCl}(\mathrm{pH} 8.3), \mathrm{MgCl}_{2}$ ranging from 1 to $2 \mathrm{mM}$ and 1.5 units of Taq Polymerase (Promega) in a final volume of $50 \mu \mathrm{l}$. PCRs were performed in a MJPT-100 thermal cycler (MJ Research, Inc., Watertown, MA, USA) or in an Eppendorf Master Cycler (Germany). In the first round of PCR (exons 4-9) the 30 cycles were $1^{\prime} 30^{\prime \prime}$ at $95^{\circ} \mathrm{C}, 1^{\prime} 30^{\prime \prime}$ at $58^{\circ} \mathrm{C}$ and $2^{\prime} 30^{\prime \prime}$ at $70^{\circ} \mathrm{C}$, followed by final extension at $70^{\circ} \mathrm{C}$ for $7^{\prime}$. PCR programs for nested PCRs were as described [18]. Negative (no DNA added) and positive (genomic DNA from characterized samples [18]) controls were regularly used for each set of PCR.

\subsection{DGGE conditions}

The PCR products obtained with the GC-clamped ampliprimers were analyzed by DGGE [18]. The introduction of a GC-clamp into the amplified fragment allows a nearly $100 \%$ detection rate of any base change within the fragment [39]. The DGGE apparatus was from CBS Scientific Co. (Del Mar, CA, USA). Parallel denaturing gradient gels were prepared with $8 \%$ acrylamide-bisacrylamide $(37: 1)$ in TAE (40 mM Tris acetate/1 mM EDTA, $\mathrm{pH}$ 8.0) and by varying denaturant concentrations (100\% denaturant corresponds to $7 \mathrm{M}$ urea and $40 \%$ formamide). The range of the denaturing gradient was different and specific for each amplified fragment [18]. Gels were run in TAE at $60^{\circ} \mathrm{C}, 50 \mathrm{~V}$ for $16-$ $20 \mathrm{~h}$. After electrophoresis, the gels were stained for $20 \mathrm{~min}$ in $0.5 \mu \mathrm{g} / \mathrm{ml}$ ethidium bromide, visualized using a UV transilluminator and photographed using Polaroid type 55 films. Once a DGGE variant was observed, a new 4000 nuclei aliquot was used through all the procedure to confirm the presence of the DGGE variant and to avoid misclassification of PCR artefacts.

\subsection{DNA sequencing}

PCR products for sequencing were obtained starting from either genomic DNA or eluted DGGE mutant homoduplex bands. The PCR products, obtained using the same primers for DGGE analysis but without "GC-clamp", were cloned into the plasmid pGEM-T (Promega, Madison, WI, USA) according to the manufacturer's instructions. The inserts of a series of independent clones were characterized by PCR-DGGE analysis. Three to 5 independent clones, showing the same mutant homoduplex band pattern as the one obtained starting from genomic DNA, were then sequenced using CircumVent(exo-) kit (New England Biolabs, Beverly, MA, USA) in the presence of $\left[\alpha^{35}\right.$ S]dATP. Sequencing reaction products were electrophoresed on 7\% polyacrylamide-7 M urea gels in TBE ( $45 \mathrm{mM}$ Tris borate/1 mM EDTA, $\mathrm{pH}$ 8.0) for $2 \mathrm{~h}$ at $50 \mathrm{~mA}$. Gels were then fixed for $15 \mathrm{~min}$ in $10 \%$ methanol and $10 \%$ acetic acid, dried, and exposed to $\beta$-MAX films (Amersham, Milan, Italy). 


\subsection{Loss of heterozygosity}

Loss of heterozygosity $(\mathrm{LOH})$ in proximity of the p53 locus was evaluated by PCR using the highly polymorphic marker YNZ22 (band 17p13.3). Primers and PCR conditions were those described by Batanian et al. [2]. Lysate from 4000 nuclei of each component of the tumour and from the control mucosa sectors, were separately used as template for PCR amplification. The primers used allow amplification of a region with a variable number of tandem repeats (VNTR). PCR products were separated on a $2 \%$ agarose gel, stained with $0.5 \mu \mathrm{g} / \mathrm{ml}$ ethidium bromide and visualized using a UV transilluminator. $\mathrm{LOH}$ was considered to have occurred when one of the 2 alleles present in PCR products obtained with control mucosa was missing from PCR products obtained from the biopsy DNA.

\subsection{Statistical analysis}

Association of p53 genetic with DNA ploidy was tested according to contingency tables by means of the Fisher's exact test [23].

\section{Results}

Figure 1 illustrates the multiple methodological steps performed for studying the presence of p53 mutations in superficial and deep infiltrating tumour sectors and in DNA diploid and aneuploid nuclei (respectively indicated by DId and DIa) obtained from 20 human colorectal adenocarcinomas.

Table 1 shows that 5 tumours had only DId nuclei while 15 tumours comprised both DIa and DId cells, the latter very likely being normal non tumour cells. Overall, DNA aneuploidy incidence was $75 \%$ for the primary tumours, $60 \%$ for the lymph node metastases (Table 2), and absent in the control mucosa (not shown). Table 1 also shows that in three out of 15 DNA aneuploid adenocarcinomas, the DIa component was only present in the superficial sectors and not in the invasive margins.

PCR-based DGGE analysis of exons 5-8 of the p53 gene was performed separately for the different components as indicated in Tables 1 and 2. This screening allowed the identification of DGGE variants which were further characterized by DNA sequencing.

Ten out of 15 DIa and none of the DId tumours showed a single p53 DGGE variant in at least one of the different components analyzed (Table 1). In one case (tumour no. 4), the control mucosa showed exactly the same variant observed in the tumour component, suggesting either a germinal mutation or a silent polymorphism. DNA sequencing of this DGGE variant indicated an AT $>\mathrm{GC}$ transition in intron 6, 31 base pairs downstream from the $3^{\prime}$ end of the exon 6 . This mutation was not predicted to create an alternative splice site and may represent a new polymorphism [10].

In all tumours but one (no. 3), superficial and deep infiltrating tumour margins shared the same DGGE variant (Table 1). In tumour no. 3, the deep infiltrating margins but not the superficial sectors showed a DGGE variant.

DGGE variants, when present, were observed in both DId and DIa cell components in all primary tumours but one (no. 13), and in the 4 metastases that showed both DId and DIa cell nuclei (Table 2). In tumour no. 13, the DGGE variant was present only in the DIa component of both superficial and deep infiltrating margin sectors.

Among the 7 lymph node metastases analyzed, 6 showed the presence of a single DGGE variant, 5 of which were identical to the one observed in the matching primary tumour and one had no mutant counterpart in the primary tumour (Tables 1 and 2). 
Table 1

Presence of p53 mutations in DNA diploid and DNA aneuploid cell components of superficial and deep infiltrating margins of human colorectal adenocarcinomas

\begin{tabular}{|c|c|c|c|}
\hline \multirow{2}{*}{$\begin{array}{c}\text { Case } \\
\text { number }\end{array}$} & \multirow{2}{*}{$\begin{array}{c}\text { Tumour }{ }^{1} \\
\text { sector }\end{array}$} & \multicolumn{2}{|c|}{ p53 DGGE variants ${ }^{2}$} \\
\hline & & DId & DIa \\
\hline \multicolumn{4}{|c|}{ Primary tumour with metastasis } \\
\hline \multirow[t]{3}{*}{1} & A & Mut (exon 6) & Mut (exon 6) \\
\hline & $\mathrm{B}$ & Mut (exon 6) & Mut (exon 6) \\
\hline & M & Mut (exon 6) & Mut (exon 6) \\
\hline \multirow[t]{3}{*}{5} & A & wt & wt \\
\hline & $\mathrm{B}$ & wt & wt \\
\hline & M & wt & -3 \\
\hline \multirow[t]{3}{*}{6} & A & Mut (exon 6) & Mut (exon 6) \\
\hline & $\mathrm{B}$ & Mut (exon 6) & Mut (exon 6) \\
\hline & M & Mut (exon 6) & Mut (exon 6) \\
\hline \multirow[t]{3}{*}{8} & A & Mut (exon 5) & Mut (exon 5) \\
\hline & $\mathrm{B}$ & Mut (exon 5) & -3 \\
\hline & M & Mut (exon 5) & $-^{3}$ \\
\hline \multirow[t]{3}{*}{9} & A & Mut (exon 8) & Mut (exon 8) \\
\hline & $\mathrm{B}$ & Mut (exon 8) & Mut (exon 8) \\
\hline & M & Mut (exon 8) & Mut (exon 8) \\
\hline \multirow[t]{3}{*}{11} & A & Mut (exon 8) & Mut (exon 8) \\
\hline & $\mathrm{B}$ & Mut (exon 8) & Mut (exon 8) \\
\hline & M & Mut (exon 8) & Mut (exon 8) \\
\hline \multirow[t]{3}{*}{20} & A & wt & -3 \\
\hline & B & wt & -3 \\
\hline & M & Mut (exon 5) & -3 \\
\hline \multicolumn{4}{|c|}{ Primary tumour without metastasis } \\
\hline \multirow[t]{2}{*}{2} & A & Mut (exon 5) & Mut (exon 5) \\
\hline & B & Mut (exon 5) & -3 \\
\hline \multirow[t]{2}{*}{3} & A & wt & wt \\
\hline & B & Mut (exon 7) & $-^{3}$ \\
\hline \multirow[t]{2}{*}{4} & A & Pol (inton 6) & Pol (inton 6) \\
\hline & B & Pol (inton 6) & Pol (inton 6) \\
\hline \multirow[t]{2}{*}{7} & A & wt & wt \\
\hline & B & wt & wt \\
\hline \multirow[t]{2}{*}{10} & A & wt & wt \\
\hline & $\mathrm{B}$ & wt & wt \\
\hline \multirow[t]{2}{*}{12} & A & Mut (exon 7) & Mut (exon 7) \\
\hline & $\mathrm{B}$ & Mut (exon 7) & Mut (exon 7) \\
\hline \multirow[t]{2}{*}{13} & A & wt & Mut (exon 6) \\
\hline & $\mathrm{B}$ & wt & Mut (exon 6) \\
\hline \multirow[t]{2}{*}{14} & A & w & wt \\
\hline & $\mathrm{B}$ & wt & wt \\
\hline \multirow[t]{2}{*}{15} & A & wt & wt \\
\hline & $\mathrm{B}$ & wt & wt \\
\hline \multirow[t]{2}{*}{16} & A & wt & -3 \\
\hline & B & wt & -3 \\
\hline
\end{tabular}


Table 1

(Continued)

\begin{tabular}{cccc}
\hline $\begin{array}{c}\text { Case } \\
\text { number }\end{array}$ & $\begin{array}{c}\text { Tumour }^{1} \\
\text { sector }\end{array}$ & DId & D53 DGGE variants \\
\cline { 3 - 4 } & A & wt & $-{ }^{3}$ \\
\hline 17 & B & wt & $-{ }^{3}$ \\
& A & wt & -3 \\
18 & B & wt & -3 \\
& A & wt & -3 \\
& B & wt & -3 \\
\hline
\end{tabular}

\footnotetext{
${ }^{1} \mathrm{~A}$ is for superficial tumour sectors; $\mathrm{B}$ is for deep infiltrating tumour margins; $\mathrm{M}$ is lymph node metastasis.

${ }^{2}$ When tumour and control mucosa samples showed identical DGGE variant, the mutation was considered of germinal origin (polymorphism, indicates as Pol); when the variant was present exclusively in the tumour the mutation was of somatic origin (indicated as Mut). DId: DNA diploid cell component, DIa: DNA aneuploid cell component.

${ }^{3}$ DNA aneuploid component was not present.

Note: $w \mathrm{t}=$ wild type.
}

Table 2

p53 mutations in DNA diploid and aneuploid cell components of lymph node metastases from human colorectal adenocarcinomas*

\begin{tabular}{ccc}
\hline Case $^{1}$ & \multicolumn{2}{c}{ p53 DGGE variants $^{2}$} \\
\cline { 2 - 3 } number & DId & DIa \\
\hline $1(1)$ & Mut (exon 6) & Mut (exon 6) \\
$2(5)$ & wt & $-^{3}$ \\
$3(6)$ & Mut (exon 6) & Mut (exon 6) \\
$4(8)$ & Mut (exon 5) & - \\
$5(9)$ & Mut (exon 8) & Mut (exon 8) \\
$6(11)$ & Mut (exon 8) & Mut (exon 8) \\
$7(20)$ & Mut (exon 5) & $-^{3}$ \\
\hline
\end{tabular}

${ }^{*}$ See details also in the legend of Fig. 1.

${ }^{1}$ Number in parenthesis refers to primary tumour number as listed Table 1.

${ }^{2}$ DId: DNA diploid cell component, DIa: DNA aneuploid cell component.

${ }^{3}$ DNA aneuploid component was not present.

Typical results of the PCR based DGGE analysis on p53 exons 8 and 7 are shown in Fig. 2 for tumours nos 11 and 12 (panels A and B, respectively). For both tumours, a robust band corresponding to the wild-type allele was visible in the DId component, along with very faint heteroduplex bands. On the contrary, the band corresponding to the mutant allele was almost the only one visible in the DIa component. A similar pattern was also observed in the DId and DIa components of the invaded lymph nodes (Fig. 2, panel A). These results indicate that only a small fraction of the alleles $(<10 \%)$ in the cell population of the DId component are variant alleles and suggest that $\mathrm{LOH}$ could have occurred in the DIa cell component. This hypothesis was confirmed for tumours 6 and 8, by LOH analysis at the highly polymorphic marker YNZ22 which maps close to the p53 gene (band 17p13.3). In both cases two alleles were present in the control mucosa and in the DId tumour cell component, while only one allele was present in the matching DIa tumour cell component (not shown). 


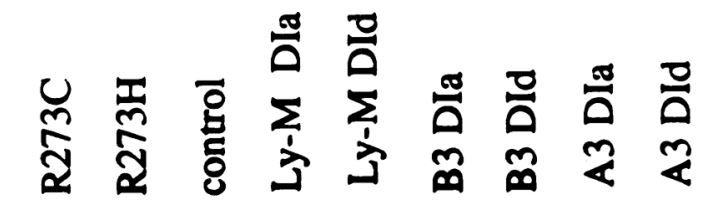

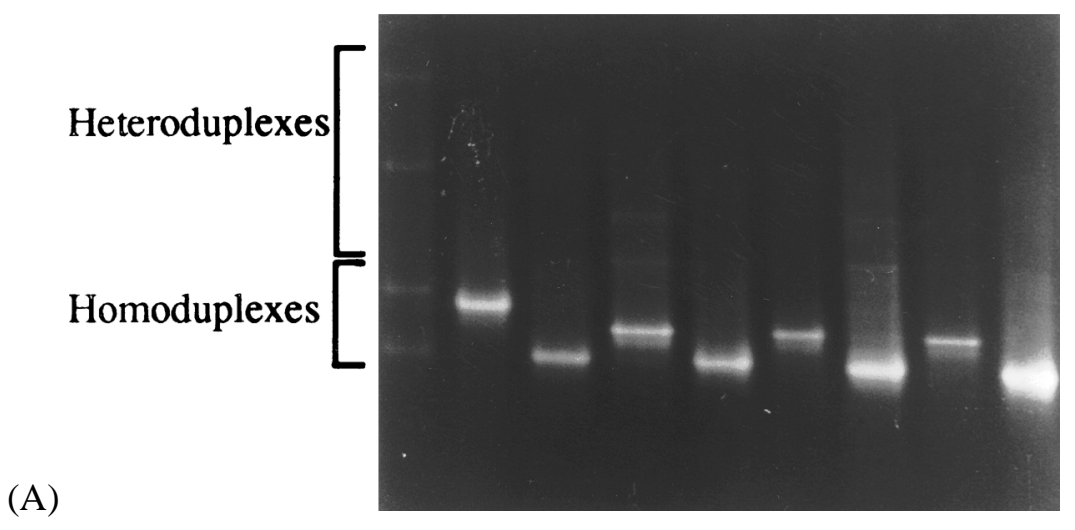

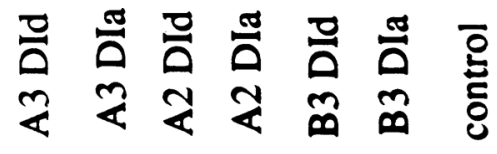

(B)

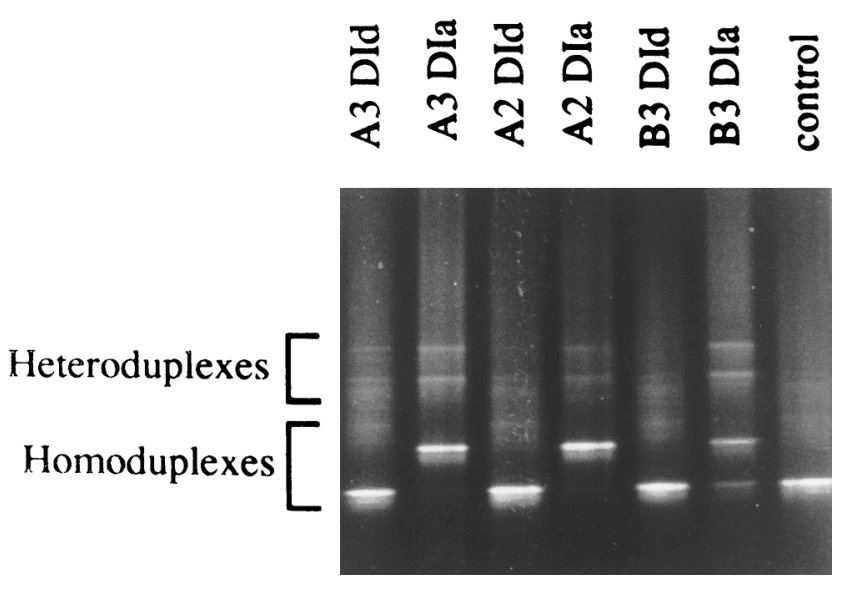

Fig. 2. PCR-based DGGE analysis of p53 gene. Panel A: analysis of exon 8 DGGE variants in tumour no. 11. R273C positive control (hemizygote for an Arg273 > Cys); R273H, positive control (homozygote for an Arg273 > His); control mucosa; lymph node metastasis (Ly-M); superficial (A) and deep (B) tumour sectors from which DIa and DId tumour cell components were sorted. The corresponding mutation is reported in Tables 2 and 3 for primary tumour and lymph node metastasis, respectively. Panel B: analysis of exon 7 in sample 12. Superficial (A) and deep (B) tumour sectors from which DNA diploid or aneuploid nuclei were sorted; control mucosa. The corresponding mutations are reported in Table 3.

Each DGGE variant was reconfirmed from a new aliquot of nuclei, and then characterized at the molecular level by DNA sequencing (Table 3, Fig. 3). Sequencing results for tumour no. 11 (GC > AT, Arg282 > Trp, right panel) and tumour no. 12 (GC > AT, Arg248 > Gln, left panel) are shown in Fig. 3. Eight out of ten p53 changes were GC $>$ AT transitions, the majority of which (6/8) involved CpG sites. The features of the mutations observed are consistent with those reported by others $[27,28]$ and suggest a major role for mutagenic events occurring at $\mathrm{CpG}$ sites. Spontaneous or enzymatic deamination of 5-methylcytosine at $\mathrm{CpG}$ sites occurs frequently in the genome and the repair of the resulting G/T mismatch is relatively inefficient, as recently shown by Schmutte et al. [38]. 
Table 3

Molecular characterization of the p53 gene mutations observed in this study*

\begin{tabular}{|c|c|c|c|c|}
\hline Tumour $^{1}$ & Exon & Mutation $^{2}$ & $\begin{array}{l}\text { Aminoacid } \\
\text { change }\end{array}$ & $\begin{array}{l}\mathrm{CpG} \\
\text { site }\end{array}$ \\
\hline \multicolumn{5}{|c|}{ Polymorphysm } \\
\hline 4 & 6 & GGA $>$ GGG & I $6:+31^{3}$ & \\
\hline \multicolumn{5}{|c|}{ Somatic mutations } \\
\hline 1 & 6 & $\mathrm{CGA}>\mathrm{TGA}$ & Arg196 > Stop & + \\
\hline 2 & 5 & $\mathrm{CAT}>\mathrm{CAG}$ & His $179>$ Gln & - \\
\hline 3 & 7 & $\mathrm{TGC}>\mathrm{TAC}$ & Cys $242>$ Tyr & - \\
\hline 6 & 6 & $\mathrm{CGA}>\mathrm{TGA}$ & Arg213 > Stop & + \\
\hline 8 & 5 & $\mathrm{CGC}>\mathrm{CAC}$ & $\operatorname{Arg} 175>$ His & + \\
\hline 9 & 8 & $\mathrm{CGT}>\mathrm{TGT}$ & Arg273 > Cys & + \\
\hline 11 & 8 & $\mathrm{CGG}>\mathrm{TGG}$ & $\operatorname{Arg} 282>\operatorname{Trp}$ & + \\
\hline 12 & 7 & $\mathrm{CGG}>\mathrm{CAG}$ & $\operatorname{Arg} 248>\operatorname{Gln}$ & + \\
\hline 13 & 6 & GTG $>$ ATG & Val216 $>$ Met & - \\
\hline 20 & 5 & $\mathrm{GAT}>\mathrm{CAT}$ & Asp184 $>$ His & - \\
\hline
\end{tabular}

${ }^{*}$ See details also in Fig. 1.

${ }^{1}$ Number of sample.

${ }^{2}$ Underlined: mutated base.

${ }^{3}$ Mutation in intron 6, 31 base pairs downstream from the $3^{\prime}$ end of exon 6, is not predicted to create an alternative splice site and may represent a new polymorphism (Campomenosi et al. [10]).

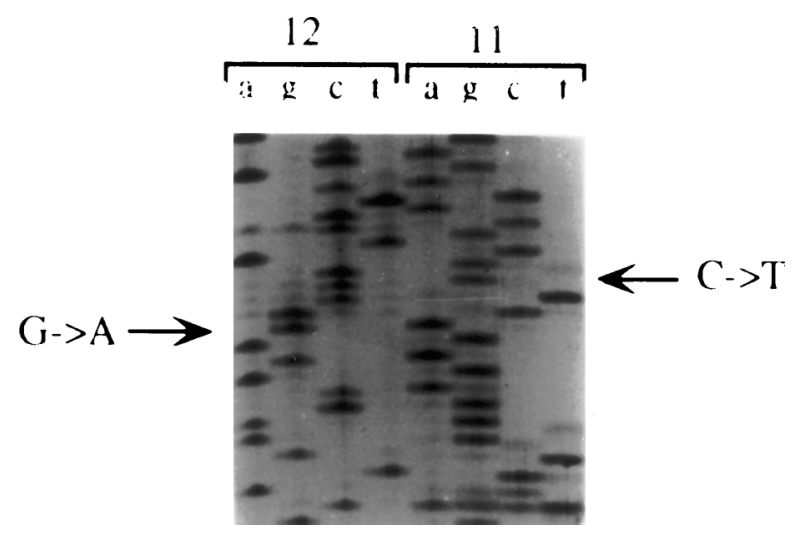

Fig. 3. Sequence analysis of DGGE variants from tumour no. 12 (left) showing a GC $>$ AT transition at codon 248 (CGG > CAG), and from tumour no. 11 (right) showing a CG > TA transition at codon 282 (CGG > TGG).

\section{Discussion}

Aneuploid cells are commonly observed in human solid tumours. This observation suggests that cellular functions that control the fidelity of chromosome segregation are lost during tumour progression. In the present study, we investigated if loss of p53, a gene known to be involved in the maintenance of genome stability, plays a role in the origin of aneuploid cells in colorectal adenocarcinomas. To this purpose DId and DIa colorectal adenocarcinomas were analyzed for the presence of p53 mutations. Cell 
subpopulations with an abnormal DNA content were detected by flow cytometry in 15 out of 20 carcinomas $(75 \%)$. None of the DNA diploid and 60\% of the DNA aneuploid tumours showed p53 mutations in the region under study (exons 5-8). Therefore, p53 mutations occurred significantly more often in DNA aneuploid than in DNA diploid tumours ( $p<0.04$, Fisher's exact test). A different situation has been reported for colorectal adenomas where p53 mutations are rare [42,43] while aneuploidy is observed in $30 \%$ of cases. Leaving aside the possibility that p53 mutations were underestimated in early adenomas, an explanation may be that different factors play a role in the generation of aneuploidy in early and late stages of colorectal carcinogenesis. In this respect it is interesting to note that cell lines transfected with human mutated K-ras2 showed chromosome instability [37], suggesting that K-ras may play a role in the generation of aneuploidy. Moreover, the high incidence and correlation with aneuploidy of $1 \mathrm{p}$ deletions among colorectal adenomas has suggested a possible role of gene(s) mapping to this chromosome locus in the control of chromosome stability $[19,20]$ also prior to p53 mutations. Therefore, it seems reasonable to envisage that both p53 dependent and p53 independent mechanisms may originate aneuploid cells during colorectal cancerogenesis [24]. In case of p53 independent mechanisms, p53 mutations could play a role in DNA aneuploid subclone selection and expansion rather than in the generation of aneuploidy.

DNA aneuploid tumours, for which we have also separately analyzed the DId cell component, showed that both DIa and DId cell components had the same p53 mutations although the relative proportion of the mutant and the wild-type alleles, as estimated by the intensity of the DGGE bands, were clearly different. Whereas the mutated allele represented the major band in the DNA aneuploid components, only very faint bands corresponding to heteroduplexes were visible in the matching DId components. Although many morphological and technical (FACS) strategies were used to enrich for epithelial tumour cells, we cannot exclude that the DId cell component found in DNA aneuploid tumour is in fact formed by normal non tumour cells. Furthermore, it is very likely that DIa nuclei cross-contaminate the DId component and viceversa. Therefore, the very faint heteroduplex bands observed in DGGE for the DId component of DNA aneuploid tumours are most probably due to cross-contamination.

In the present study, we have also partly addressed the problem of the intratumour homogeneity of p53 mutations [9]. We are well aware that this question would require the separate analysis of many more samples than we have done (one mixed sample for superficial sites and one for deep infiltrating sites). The present series of cases suggests that there is no difference in the incidences of p53 mutations between superficial and invasive tumour margins.

In conclusion, we showed that p53 mutations occur more frequently in DNA aneuploid than in DNA diploid tumours and that cells of the DIa cell component showed the presence of a single mutant allele, apparently generated by two hits: p53 mutation and LOH. The finding that the same mutation was observed in lymph node metastases indicates that proximal lymph node metastases are clonal with respect to the primary tumour and may be originated by the p53-/- aneuploid cells, at least in the cases presently under study.

\section{Acknowledgements}

This work was supported by the National Research Council (grant no. 96.00708.PF39), by the Italian Association for Cancer Research (AIRC, Tumori colorettali ereditari) and by the contract CHRX-CT940581 of the Commission of the European Communities. 


\section{References}

[1] V.B. Astler and F.A. Coller, The prognostic significance of direct extension of carcinoma of the colon and rectum, Ann. Surg. 139 (1954), 846-851.

[2] R. Batanian, S.A. Ledbetter, R.K. Wolff, Y. Nakamura, R. White, W.B. Dobyns and D.H. Ledbetter, Rapid diagnosis of Miller-Dieker syndrome and isolated lissencephaly sequence by the polymerase chain reaction, Hum. Genet. 85 (1990), $555-559$.

[3] F.Z. Bischoff, S.O. Yim, S. Pathak, G. Grant, M.J. Siciliano, B.C. Giovanella, L.C. Strong and M.A. Tainsky, Spontaneous abnormalities in normal fibroblasts from patients with Li-Fraumeni cancer syndrome: aneuploidy and immortalization, Cancer Res. 50 (1990), 7979-7984.

[4] P.L. Blount, P.C. Galipeau, C.A. Sanchez, K. Neshat, D.S. Levine, J. Yin, H. Suzuki, J.M. Abraham, S.J. Meltzer and B.J. Reid, 17p allelic losses in diploid cells of patients with Barrett's esophagus who develop aneuploidy, Cancer Res. 54 (1994), 2292-2295.

[5] J.R. Bos, E.R. Fearon, S.R. Hamilton, M. Verlaan de Vries, J.H. van Boom, A.J. van der Eb and B. Vogelstein, Prevalence of ras gene mutations in human colorectal cancers, Nature 327 (1987), 293-297.

[6] G.C. Burmer and L.A. Loeb, Mutations in the KRAS2 oncogene during progressive stages of human colon carcinoma, Proc. Natl. Acad. Sci. 86 (1989), 2403-2407.

[7] G.C. Burmer, P.S. Rabinovitch, R.C. Haggit, D.A. Crispin, T.A. Brentnall, V.R. Kolli, A.C. Stevens and C.E. Rubin, Neoplastic progression in ulcerative colitis: histology, DNA content, and loss of a p53 allele, Gastroenterology 103 (1992), $1602-1610$.

[8] A.L. Børresen, E. Hovig, B. Smith-Sörensen, D. Malkin, S. Lystad, T.I. Andersen, J.M. Nesland, K.J. Isselbacher and S.H. Friend, Constant denaturant gel electrophoresis as a rapid screening technique for p53 mutations, Proc. Natl. Acad. Sci. 88 (1991), 8405-8409.

[9] A. Calugi, P. Eleuteri, D. Cavallo, G. Naso, L. Albonici, M.P. Lombardi, V. Manzari, C. Romanini and R. DeVita, Detection of cellular heterogeneity by DNA ploidy, 17 chromosome and p53 gene in primary carcinoma and metastasis in a case of ovarian cancer, Int. J. Gynecol. Pathol. 15 (1996), 77-81.

[10] P. Campomenosi, M. Conio, M. Bogliolo, S. Urbini, P. Assereto, A. Aprile, P. Monti, H. Aste, G. Lapertosa, A. Inga, A. Abbondandolo and G. Fronza, p53 is frequently mutated in Barret's metaplasia of the intestinal type, Cancer Epidemiol. Biomark. Prevent. 5 (1996), 559-565.

[11] L.A. Cannon-Albright, M.H. Skolnick, D.T. Bishop, R.G. Lee and R.W. Burt, Common inheritance of susceptibility to colonic adenomatous polyps and associated colorectal cancers, New Engl. J. Med. 319 (1988), 533-537.

[12] P.J. Carder, A.H. Wyllie, C.A. Purdie, R.G. Morris, S. White, J. Piris and C.C. Bird, Stabilised p53 facilitates aneuploid clonal divergence in colorectal cancer, Oncogene 8 (1993), 1397-1401.

[13] P.J. Carder, K.J. Cripps, R. Morris, S. Collins, S. White, C.C. Bird and A.H. Wyllie, Mutation of the p53 gene precedes aneuploid clonal divergence in colorectal carcinoma, Br. J. Cancer 71 (1995), 215-218.

[14] Y. Cho, S. Gorina, P.D. Jeffrey and N.P. Pavletich, Crystal structure of p53 tumour suppressor-DNA complex: understanding tumourigenic mutations, Science 265 (1994), 346-355.

[15] A. Costa, R. Marasca, B. Valentinis, M. Savarino, A. Faranda, S. Silvestrini and G. Torelli, p53 gene point mutations in relation to p53 nuclear protein accumulation in colorectal cancers, J. Pathol. 176 (1995), 45-53.

[16] K.J. Cripps, C.A. Purdie, P.J. Carder, S. White, K. Komine, C.C. Bird and A.H. Wyllie, A study of stabilization of p53 versus point mutation in colorectal carcinoma, Oncogene 9 (1994), 2734-2743.

[17] Y. Cross, C.A. Sanchez, C.A. Morgan, M.K. Schimke, S. Ramel, R.L. Idzerda, W.H. Raskind and B.J. Reid, A p53dependent mouse spindle checkpoint, Science 267 (1995), 1353-1355.

[18] F. D’ Agostini, G. Fronza, P. Campomenosi, A. Izzotti, G.L. Petrilli, A. Abbondandolo and S. De Flora, Cancer biomarkers in human atherosclerotic lesions. No evidence of p53 involvement, Cancer Epidemiol. Biomark. Prevent. 4 (1995), 111115.

[19] A. Di Vinci, E. Infusini, C. Peveri, M. Risio, F.P. Rossini and W. Giaretti, Deletions at chromosome 1p by fluorescence in situ hybridization are an early event in human colorectal tumourigenesis, Gastroenterology 111 (1996), 102-107.

[20] A. Di Vinci, E. Infusini, C. Peveri, A. Sciutto, M. Risio, F.P. Rossini and W. Giaretti, Correlation between 1p deletions and aneusomy in human colorectal adenomas, Int. J. Cancer 73 (1997), 1-6.

[21] E.R. Fearon and B. Vogelstein, A genetic model for colorectal tumourigenesis, Cell 61 (1990), 759-767.

[22] R. Fishel, M.K. Lescoe, M.S.R. Rao, N.G. Copeland, N.A. Jenkins, J. Garber, M. Kane and R. Kolodner, The human mutator gene homolog MSH2 and its association with hereditary nonpolyposis colon cancer, Cell 75 (1993), 1027-1038.

[23] J.L. Fleiss, Statistical Methods for Rates and Proportions, 2nd edn, Wiley, New York, 1988.

[24] W. Giaretti, A model of DNA aneuploidization and evolution in colorectal cancer, Lab. Invest. 71 (1994), 904-910.

[25] W. Giaretti, N. Pujic, A. Rapallo, S. Nigro, A. Di Vinci, E. Geido and M. Risio, K-ras2 G-C and G-T transversions correlate with DNA aneuploidy in colorectal adenomas, Gastroenterology 108 (1995), 1040-1047.

[26] W. Giaretti, W.R. Monaco, N. Pujic, A. Rapallo, S. Nigro and E. Geido, Intratumour heterogeneity of K-ras2 mutations in 
colorectal adenocarcinomas. Association with degree of DNA aneuploidy and S-phase fraction, Am. J. Pathol. 149 (1996), 237-245.

[27] M.S. Greenblatt, W.P. Bennett, M. Hollstein and C.C. Harris, Mutations in the p53 tumour suppressor gene: clues to cancer etiology and molecular pathogenesis, Cancer Res. 54 (1994), 4855-4878.

[28] M. Hollstein, B. Shomer, M. Greenblatt, T. Soussi, E. Hovig, R. Montesano and C.C. Harris, Somatic point mutations in the p53 gene of human tumours and cell lines: updated compilation, Nucl. Acids Res. 24 (1996), 141-146.

[29] D. Lane, p53, the guardian of the genome, Nature 358 (1992), 15-16.

[30] F.S. Leach, N.C. Nicolaides, N. Papadopoulos, B. Liu, J. Jen, R. Parson, P. Peltomäki, P. Sistonen, L.A. Aaltonen, M. Nyström-Lahti, X.Y. Guan, J. Zhang, P.S. Meltzer, J.W. Yu, F.T. Kao, D.J. Chen, K.M. Cerosaletti, R.E.K. Fournier, S. Todd, T. Lewis, R.J. Leach, S.L. Naylor, J. Weissenbach, J.P. Mecklin, H. Järvinen, G.M. Petersen, S.R. Hamilton, J. Green, J. Jass, P. Watson, H.T. Lynch, J.M. Trent, A. de la Chapelle, K.W. Kinzler and B. Vogelstein, Mutations of a mutS homolog in hereditary nonpolyposis colorectal cancer, Cell 75 (1993), 1215-1225.

[31] G.I. Meling, R.A. Lothe, A.L. Børresen, C. Graue, S. Hauge, O.P.F. Clausen and T.O. Rognum, The TP53 tumour suppressor gene in colorectal carcinomas. II. Relation to DNA ploidy pattern and clinicopathological variables, Br. J. Cancer 67 (1993), 93-98.

[32] B.C. Morson and L.H. Sobin, Histological typing of intestinal tumours, in: International Histological Classification of Tumours, WHO, Geneva, 1976, pp. 14-35.

[33] T. Muto, H.J.R. Bussey and B.C. Morson, The evolution of cancer of the colon and rectum, Cancer 36 (1975), 2251-2270.

[34] K. Neshat, C.A. Sanchez, P.C. Galipeau, P.L. Blount, D.S. Levine, G. Joslyn and B.J. Reid, p53 mutations in Barrett's adenocarcinoma and high-grade dysplasia, Gastroenterology 106 (1994), 1589-1595.

[35] N.C. Nicolaides, N. Papadopoulos, B. Liu, Y.F. Wei, K.C. Carter, S.M. Ruben, C.A. Rosen, W.A. Haseltine, R.D. Fleischmann, C.M. Fraser, M.D. Adams, J.C. Venter, M.G. Dunlop, S.R. Hamilton, G.M. Petersen, A. de la Chapelle, B. Vogelstein and K.W. Kinzler, Mutations of two PMS homologues in hereditary nonpolyposis colon cancer, Nature 371 (1994), $75-80$.

[36] J.M. Nigro, S.J. Baker, A.C. Preisinger, J.M. Jessup, R. Hostetter, K. Cleary, S.H. Bigner, N. Davidson, S. Baylin, P. Devilee, T. Glover, F.S. Collins, A. Weston, R. Modali, C.C. Harris and B. Vogelstein, Mutations in the p53 gene occur in diverse tumour types, Nature 342 (1989), 705-708.

[37] S. Nigro, E. Geido, E. Infusini, R. Orecchia and W. Giaretti, Transfection of human mutated K-ras in mouse NIH-3T3 cells is associated with increased coloning efficiency and DNA aneuploidization, Int. J. Cancer 67 (1996), 871-875.

[38] C. Schmutte, A.S. Yang, R.W. Beart and P.A. Jones, Base excision repair of U: G mismatches at a mutational hotspot in the p53 gene is more efficient than base excision repair of $\mathrm{T}: \mathrm{G}$ mismatches in extracts of human colon tumours, Cancer Res. 55 (1995), 3742-3746.

[39] V.C. Sheffield, D.R. Cox, L.S. Lerman and R.M. Myers, Attachement of a 40-base-pair G+C-rich sequence (GC-clamp) to genomic DNA fragments by the polymerase chain reaction results in improved detection of single-base changes, Proc. Natl. Acad. Sci. 86 (1989), 232-236.

[40] E. Solomon, R. Voss, V. Hall, W.F. Bodmer, J.R. Jass, A.J. Jeffreys, F.C. Lucibello, I. Patel and S.H. Rider, Chromosome 5 allele loss in human colorectal carcinomas, Nature 328 (1987), 616-619.

[41] J.P. Sugarbaker, L.L. Gunderson and R.E. Wittes, Colorectal cancer, in: Cancer: Principles and Practices of Oncology, 2nd edn, J.B. Lippincott, Philadelphia, PA, 1985, pp. 800-803.

[42] B. Vogelstein, E.R. Fearon, S.R. Hamilton, S.E. Kern, A.C. Preisinger, B.A.M. Leppert, Y. Nakamura, R. White, A.M.M. Smits and J.L. Bos, Genetic alterations during colorectal-tumour development, New Engl. J. Med. 319 (1988), $525-532$.

[43] B. Vogelstein, E.R. Fearon, S.E. Kern, S.R. Hamilton, A.C. Preisinger, Y. Nakamura and R. White, Allelotype of colorectal carcinomas, Science 244 (1989), 207-211. 


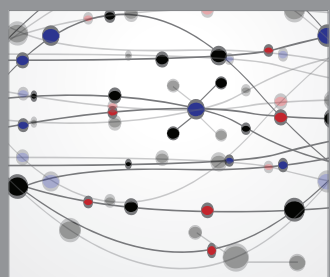

The Scientific World Journal
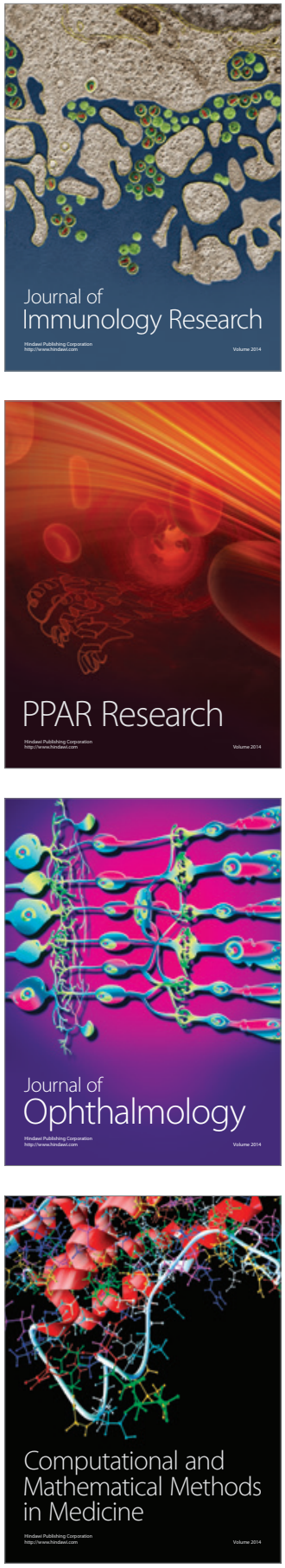

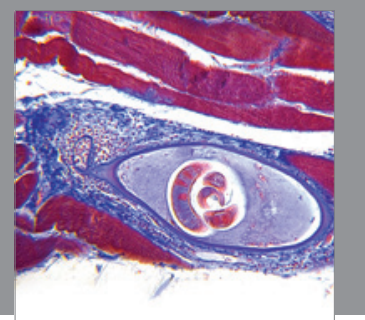

Gastroenterology

Research and Practice
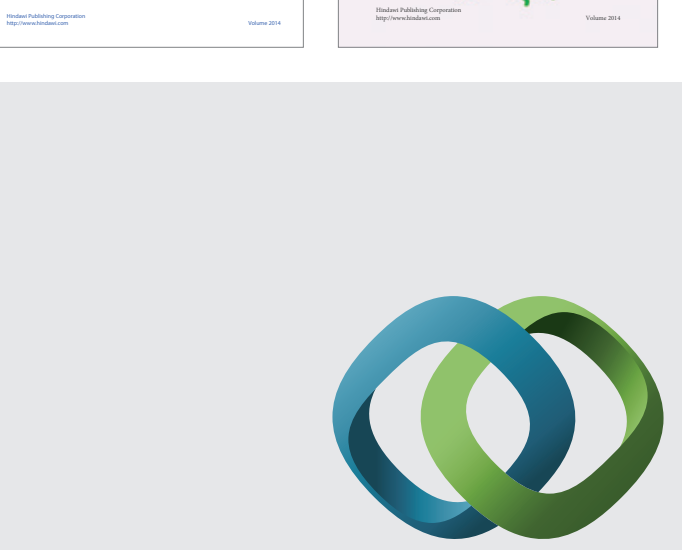

\section{Hindawi}

Submit your manuscripts at

http://www.hindawi.com
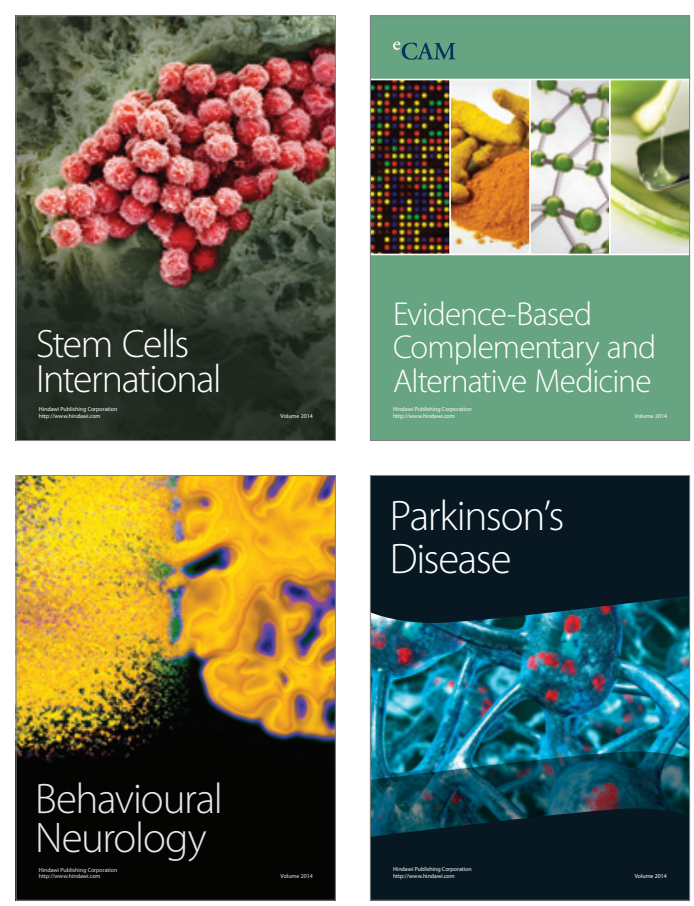

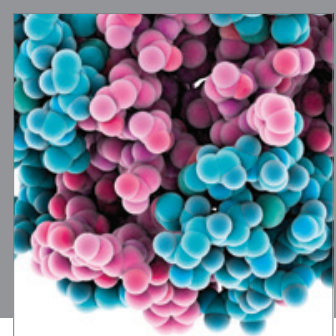

Journal of
Diabetes Research

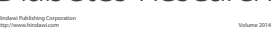

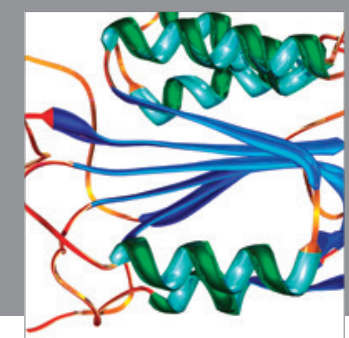

Disease Markers
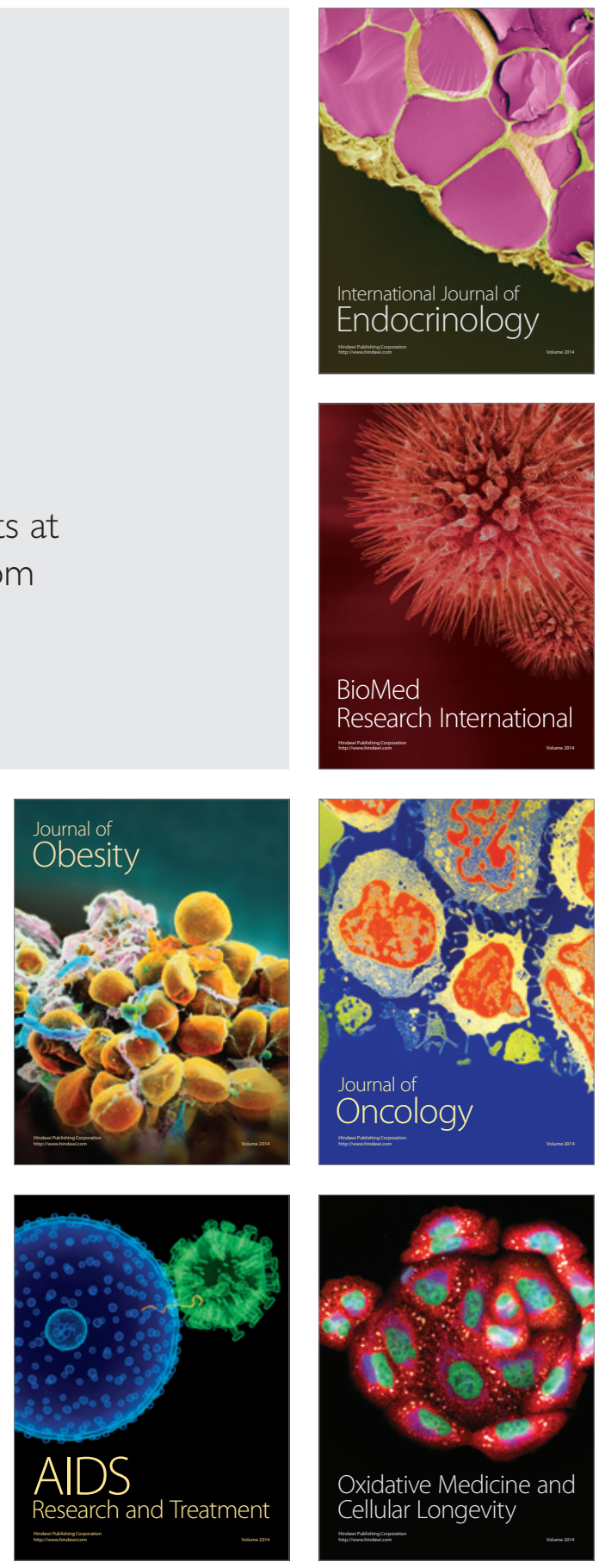